\title{
Idade, Sexo, Ocupação e Nacionalidade dos Escravos Charqueadores (1780-1888)*
}

\author{
Jorge Euzébio Assumpção**
}

O Rio Grande do Sul teve uma ocupação tardia, em relação ao restante do país. À exceção do gado, a região meridional não apresentava grandes atrativos econômicos que justificassem um empenho, por parte de Portugal, para sua real ocupação. Mesmo assim, o Extremo Sul mereceu uma atenção especial dos lusitanos. Isso se deve à sua posição geopolítica, já que esta área era foco de litígio entre os países ibéricos, que lutavam por um avanço das fronteiras de suas colônias americanas. Desta maneira, a ocupação do sul brasileiro ocorreu devido a interesses políticos, militares e econômicos. Os paulistas se beneficiavam do tráfico de aborígenes e da exploração do gado realizado nesta região.

No sul do Brasil, a presença do negro escravo já era constatada nas bandeiras de aprisionamento, como a de Repouso Tavares, de $1635 .{ }^{1}$ Mas foi a partir da fundação do Rio Grande luso-brasileiro e do surgimento das charqueadas, sobretudo das localizadas junto ao arroio Pelotas, que a figura do negro escravizado assumiu importância máxima para a história sulina.

Salvo engano, a primeira grande charqueada foi fundada por José Pinto Martins, em $1780 .{ }^{2}$ Embora o ato de charquear já fosse conhecido na região, ele alcançou maior estabilidade com os estabelecimentos pelotenses. O charque impulsionou a economia gaficha tornando-se o principal produto da região. Em 1814, 77 anos após a criação oficial do Rio Grande lusitano e 34 anos depois da criação do primeiro grande

\footnotetext{
* Agradecemos a leitura do Prof. Dr. Mário Maestri.

** Mestrando da Pontifícia Universidade Católica do RS.
} 
estabelecimento saladeril pelotense, o charque ocupava o terceiro lugar nas importações provinciais, antecedido pelo trigo e couro.

Em 1821, o mesmo passou a encabeçar a lista das exportações gaúchas. Em 1861, a carne salgada era responsável por 37,7\% das vendas e os couros por $37,2 \%$. Desta forma, $74,9 \%$ das exportações da província eram representadas por produtos das charqueadas. ${ }^{3}$

No ano de 1822 , existiam nos arredores de Pelotas cerca de 22 charqueadas em funcionamento. ${ }^{4}$ Pelotas mantinha a primazia das exportações gaúchas. Era a cidade mas rica da província, sendo as charqueadas responsáveis por este desenvolvimento e riqueza.

Quem eram os produtores diretos?

A produção de carne seca era obtida, basicamente, pela mão-deobra escrava. Isso porque o homem livre negava-se a trabalhar nas charqueadas devido às péssimas condiçōes de vida e labuta. Sendo assim, coube ao negro escravizado a manutenção dos estabelecimentos saladeiris. Uma boa charqueada tinha, em média, 80 escravos, ${ }^{5}$ mas encontraremos algumas com mais de 100 escravos. A charqueada do barão de Butuhi, entre outras, possuía o número expressivo de 142 escravos. ${ }^{6} \mathrm{Na}$ opinião de Dreys: "[...] uma charqueada bem administrada é um estabelecimento penitenciário"?

Após estas considerações, resta-nos algumas outras sobre os produtores diretos das charqueadas: - Quem eram esses produtores? - De onde vieram? - Quais suas ocupações? - Qual sua idade média? Ao respondermos estes questionamentos, teremos um perfil dos escravos negros, os principais responsáveis pela maior parte das divisas do RS antigo. Assim estaremos, também, oferecendo uma pequena contribuição para a identificação, mais precisa, da população africana no Rio Grande do Sul.

O trabalho será elaborado através de três momentos:

a) de 1780 , quando do surgimento da primeira grande charqueada, até 1831 , quando da lei que proibiu - ao menos formalmente - o tráfico de escravos da África;

b) de 1831 até 1850 - espaço de tempo entre a proibição formal do tráfico, devido a pressões estrangeiros, até a decisão política de realmente acabar com o mesmo através da lei Eusébio de Queiróz;

c) $1850-1888$ - da proibição do transporte de homens negros escravizados, da África para o Brasil, decretando a falência futura do regime escravocrata, até a assinatura da Lei Áurea. 
A fonte de pesquisa utilizada foram os inventários da freguesia de Pelotas. (Anexo I)

Os primeiros 51 anos estudados apresentam somente sete inventários. Para o segundo período, que compreende 19 anos, foram encontrados três testamentos, o que restringe a análise feita. Já a terceira etapa, que abrange 38 anos, apresenta 32 documentos. Este será o maior de todos os grupos. Ele permitirá uma conclusão mais segura, devido ao número expressivo de inventários. Dos anos 1780 a 1831, foram computados 522 homens escravizados. Destes, 137 eram crioulos; 209 possuíam nacionalidade desconhecida e 176 eram africanos. Destacando-se entre os africanos cinco moçambiques, cinco guiçamás, sete cabindas, 14 monjolos, 22 minas, 23 benguelas, 23 rebolos, 30 congos e 136 crioulos, como mostra o quadro a seguir.

\section{TABELA 1}

Nacionalidade dos escravos pertencentes aos charqueadores pelotenses

\begin{tabular}{lcc}
\hline Nacionalidades & $\mathbf{N}^{\circ}$ de Escravos & Percentagem \\
\hline Africanos & 10 & 1,8 \\
Angola & 16 & 3,1 \\
Bengala & 02 & 0,4 \\
Benguella & 23 & 4,5 \\
Cabinda & 07 & 1,2 \\
Cabundá & 02 & 0,4 \\
Calabar & 01 & 0,2 \\
Caçanje & 04 & 0,8 \\
Camundá & 02 & 0,4 \\
Catumina & 01 & 0,2 \\
Crioulos & 137 & 26,1 \\
Congo & 30 & 5,6 \\
Corange & 01 & 0,2 \\
Gaboa & 01 & 0,2 \\
Guanguila & 02 & 0,4 \\
Guiana & 01 & 0,2 \\
Guiçamá & 055 & 0,9 \\
Hanças & 011 & 0,2 \\
Manjube & 02 & 0,4 \\
Mina & 22 & 4,1 \\
Monjolo & 14 & 2,7 \\
Moçambique & 05 & 0,9 \\
Rebollo & 23 & 4,5 \\
Songa & 01 & 0,2 \\
Desconhecidos & 209 & 40,0 \\
\hline TOTAL & 522 & $100 \%$ \\
\hline
\end{tabular}

FONTE: Inventários $1^{\circ}$ e $2^{\circ}$ Cartório de Órfāos de Pelotas. Periodo de 1780-1831. Arquivo Público do Estado do RS.

- Soma-se aos 136 crioulos um procedente da provincia do Rio de Janeiro. 
No que se retere a idade dos escravos, no período tratado, teremos homens escravizados relativamente jovens. Pois, dos escravos com idade conhecida, constata-se que $71,1 \%$ tinham menos de 40 anos e $48,2 \%$ apresentavam idade inferior a 30 anos.

TABELA 2

Idade dos escravos pertencentes aos charqueadores pelotenses

\begin{tabular}{lcc}
\hline Idade & $\mathbf{N}^{\circ}$ de Escravos & Percentagem \\
\hline $0-10$ & 55 & 10,4 \\
$10-20$ & 38 & 7,3 \\
$20-30$ & 66 & 12,5 \\
$30-40$ & 75 & 14,4 \\
$40-50$ & 49 & 9,4 \\
$50-60$ & 27 & 5,2 \\
$60-70$ & 17 & 3,3 \\
$70-80$ & 02 & 0,4 \\
Indeterminado & 193 & 37,0 \\
\hline TOTAL & 5212 & $100 \%$ \\
\hline
\end{tabular}

FONTE: Inventário do $1^{\circ}$ e $2^{\circ}$ Cartório de Órfãos de Pelotas. Período de 1780-1831. Arquivo Público do Estado do RS.

O quadro anterior vem comprovar o baixo índice de escravos com idade avançada, pois temos apenas dois elementos acima de 70 anos, ficando $28,9 \%$ entre 40 e 60 anos de idade. Tais fatos demonstram, nas charqueadas, o pouco uso do negro escravizado com idade avançada e a grande utilização de produtores jovens.

No que se refere ao sexo, temos um total de 522 escravos, subdivididos em 431 homens e 91 mulheres. O sexo masculino representa $82,6 \%$ e o feminino $17,4 \%$.

TABELA 3

Sexo dos escravos pertencentes aos charqueadores pelotenses

\begin{tabular}{lccc}
\hline Homens & Percentual & Mulheres & Percentual \\
\hline 431 & 82,6 & 91 & 17,4 \\
\hline
\end{tabular}

FONTE: Inventários do $1^{\circ}$ e $2^{\circ}$ Cartório de Óffãos de Pelotas. Período de 1780-1831. Arquivo Público do Estado do RS. 
É digno de nota o número de escravos pertencentes a José da Costa Santos - 183 escravos - dos quais 42 eram mulheres e 141 homens. Se compararmos o total dos escravos do período com o do inventário citado, teremos os seguintes dados: $42,2 \%$ das escravas e $32,6 \%$ dos escravos pertenciam a um mesmo dono. Estes dados mostram o elevado índice de escravas em poder do charqueador José da Costa, em relação ao percentual geral e, conseqüentemente, aos outros proprietários.

O espaço de tempo estudado relaciona-se ao período que compreendia o ano de 1831, quando foi extinto formalmente o tráfico de africanos, devido a pressões inglesas, e se estende até o ano de 1850, quando, por meio da Lei Eusébio de Queiróz, acabou definitivamente o tráfico negreiro.

\section{TABELA 4}

Nacionalidade dos escravos pertencentes aos charqueadores pelotenses

\begin{tabular}{lcc}
\hline Nacionalidade & $\mathbf{N}^{\circ}$ de Escravos & Percentagem \\
\hline Africanos & 01 & 0,5 \\
Angola & 01 & 0,5 \\
Bengala & 01 & 0,5 \\
Crioulo & 10 & 4,8 \\
Congo & 04 & 1,9 \\
Cabinda & 01 & 0,5 \\
Nago & 06 & 2,9 \\
Indeterminado & 186 & 88,6 \\
\hline TOTAL & 210 & $100 \%$ \\
\hline
\end{tabular}

FONTE: Inventário do $1^{\circ} \mathrm{e} 2^{\circ}$ Cartório de Órăos de Pelotas. Periodo de 1831-1850. Arquivo Público do Estado do RS.

O reduzido número de inventários encontrados, neste espaço de tempo, não permite uma conclusão definitiva sobre os efeitos que a lei de 1831 teve no Rio Grande do Sul. É necessário, para tanto, utiliza outras fontes que possam elucidar esta questão. Todavia, baseando-nos no quadro anterior, podemos afirmar, apesar do número excessivo de escravos com nacionalidade indeterminada [perfazem um total de $88,6 \%$ ], que preponderam os elementos africanos em detrimento dos 
crioulos. Aqueles somavam 14 elementos, enquanto os nascidos no Brasil contavam apenas dez. Destacavam-se: os congos, 4 pessoas; os nagôs, 6 . Os demais apresentavam apenas um indivíduo.

No que se refere à idade, podemos afirmar, em cima dos dados colhidos, que no período de $1831-1850,57 \%$ da escravaria era jovem, apresentando menos de 40 anos. Concentrando-se a grande maioria na faixa de 30 a 40 anos. Num valor percentual de $41,3 \%$.

É interessante destacar a existência de um escravo de nome Manoel Bolieiro, com idade de 89 anos, avaliado em duzentos mil réis, de propriedade de Francisca Alexandrina de Castro. E um outro, com 90 anos, pertencente a Joaquim Maia da Silva, avaliado em dez mil réis.

TABELA 5

Idade dos escravos pertencentes aos charqueadores pelotenses

\begin{tabular}{lcc}
\hline Idade & $\mathrm{N}^{\bullet}$ de Escravos & Percentagem \\
\hline $0-10$ & 08 & 3,8 \\
$10-20$ & 16 & 7,6 \\
$20-30$ & 09 & 4,3 \\
$30-40$ & 87 & 41,3 \\
$40-50$ & 49 & 23,2 \\
$50-60$ & 23 & 10,9 \\
$60-70$ & 08 & 3,8 \\
$70-80$ & 02 & 0,9 \\
$80-90$ & 01 & 0,5 \\
900100 & 01 & 0,5 \\
Indeterminado & 06 & 2,9 \\
\hline TOTAL & 210 & $100 \%$ \\
\hline
\end{tabular}

FONTE: Inventário do $1^{\circ}$ e $2^{\circ}$ Cartório de Órfãos de Pelotas. Período de 1831-1850. Arquivo Público do Estado do RS.

Dos 210 escravos levantados, no período, temos 30 mulheres e 180 homens. Os homens escravizados atingem um percentual de $85,7 \%$ e as mulheres $14,3 \%$. 
Idade, sexo, ocupação e...

TABELA 6

Sexo dos escravos pertencentes aos charqueadores pelotenses

\begin{tabular}{lccc}
\hline Homens & Percentagem & Mulheres & Percentagem \\
\hline 180 & 85,7 & 30 & 14,3 \\
\hline
\end{tabular}

FONTE: Inventário de $1^{\circ}$ e $2^{\circ}$ Cartório de Órfăos de Pelotas. Periodo de 1831-1850. Arquivo Público do Estado do RS.

O último período da escravidão, a ser tratado neste trabalho, será o que compreendia os anos de 1850 - quando foi extinto, de vez, o tráfico de escravos, através da Lei Eusébio de Queiróz, até a assinatura da chamada Lei Áurea, em 1888. Vamos ter a seguinte configuração da escravaria das charqueadas pelotenses.

TABELA 7

Nacionalidade dos escravos pertencentes aos charqueadores pelotenses

\begin{tabular}{|c|c|c|}
\hline Nacionalidade & $N^{\bullet}$ de Escravos & Percentagem \\
\hline Africanos & 375 & 23,4 \\
\hline Angico & 01 & 0,06 \\
\hline Angola & 11 & 0,7 \\
\hline Bengala & 05 & 0,2 \\
\hline Benguella & 06 & 0,4 \\
\hline Bujimim & 02 & 0,1 \\
\hline Bundá & 01 & 0,06 \\
\hline Cabare & 01 & 0,06 \\
\hline Cabinda & 08 & 0,5 \\
\hline Cabo Verde & 02 & 0,1 \\
\hline Calabar & 02 & 0,1 \\
\hline Camageron & 01 & 0,06 \\
\hline Camundá & 02 & 0,1 \\
\hline Caturra & 02 & 0,1 \\
\hline Crioulo & 460 & 25,4 \\
\hline Congo & 07 & 0,3 \\
\hline Costa da África & 02 & 0,1 \\
\hline Gamba & 01 & 0,06 \\
\hline Majumbe & 01 & 0,06 \\
\hline Mina & 98 & 6,1 \\
\hline Monjolo & 05 & 0,2 \\
\hline Moçambique & 31 & 1,8 \\
\hline Nagó & 16 & 0,1 \\
\hline São Tomé & 01 & 0,06 \\
\hline Indeterminados & 556 & 34,7 \\
\hline TOTAL & 1604 & $100 \%$ \\
\hline
\end{tabular}

FONTE: Inventário do $1^{\circ}$ e $2^{\circ}$ Cartório de Órfíos de Pelotsa. Período 1850-188s. Arquivo Público do Batado do RS. 


\section{TABELA 8|}

Discriminação dos escravos crioulos com províncias determinadas, pertencentes aos charqueadores pelotenses

\begin{tabular}{lcc}
\hline Província & $N^{\circ}$ de Escravos & Percentagem \\
\hline Maranhão & 01 & 0,1 \\
Ceará & 08 & 1,6 \\
Bahia & 21 & 4,6 \\
Pernambuco & 07 & 1,4 \\
Piratini & 02 & 0,3 \\
Rio de Janeiro & 05 & 1,1 \\
Aracaly & 02 & 0,3 \\
Paraỉba & 01 & 0,1 \\
São Paulo & 01 & 0,1 \\
Santa Catarina & 04 & 0,7 \\
Sergipe & 01 & 0,1 \\
Indeterminados & 407 & 88,5 \\
\hline TOTAL & 460 & $100 \%$ \\
\hline
\end{tabular}

FONTE: Inventário do $1^{\circ} \mathrm{e} 2^{\circ}$ Cartório de Órfãos de Pelotas. Periodo 1850-1888. Arquivo Público de Estado do RS.

Foi possível apurar 1604 escravos, onde 460 eram crioulos, 556 indeterminados e 590 africanos. Estes dados demonstram a superioridade numérica dos africanos em relação aos crioulos, a que pese a extinção do tráfico negreiro. As principais nações representadas eram: congo 7; cabinga 8; angola 11; nagô 16 ; moçambique 31 e mina 98.

No que se refere a idade, podemos dizer que $45,9 \%$ dos escravos estavam abaixo de 40 anos e $54,1 \%$ entre 40 e 90 anos.

Nota-se assim, um aumento da população acima de 40 anos. 
Idade, sexo, ocupação e ...

TABELA 9

Idade dos escravos pertencentes aos charqueadores pelotenses

\begin{tabular}{lcc}
\hline Idade & $\mathbf{N}^{\bullet}$ de Escravos & Percentagem \\
\hline $0-10$ & 69 & 4,3 \\
$10-20$ & 101 & 6,3 \\
$20-30$ & 218 & 13,6 \\
$30-40$ & 350 & 21,7 \\
$40-50$ & 394 & 24,6 \\
$50-60$ & 229 & 14,3 \\
$60-70$ & 105 & 6,4 \\
$70-80$ & 29 & 1,8 \\
$80-90$ & 03 & 0,2 \\
$90-100$ & - & 6,6 \\
Indeterminados & 106 & $100 \%$ \\
\hline TOTAL & 1604 & \\
\hline
\end{tabular}

FONTE: Inventário do $1^{\circ} \mathrm{e} 2^{\circ}$ Cartório de Órfãos de Pelotas. Período 1850-1888. Arquivo Público de Estado do RS.

No último período da escravatura a que nos referimos, levantamos um total de 1604 homens escravizados. Dos quais 195 são mulheres e 1409 homens. Sendo assim, temos $87,8 \%$ de escravos e $12,2 \%$ de escravos, como mostra a tabela.

TABELA 10

Sexo dos escravos pertencentes aos charqueadores pelotenses

\begin{tabular}{lccc}
\hline Homens & Percentagem & Mulheres & Percentagem \\
\hline 1409 & 87,8 & 195 & 12,2 \\
\hline
\end{tabular}




\section{Conclusão}

Após uma análise nestes dados, podemos dizer que nos três períodos estudados, a figura do escravo africano supera numericamente ao crioulo.
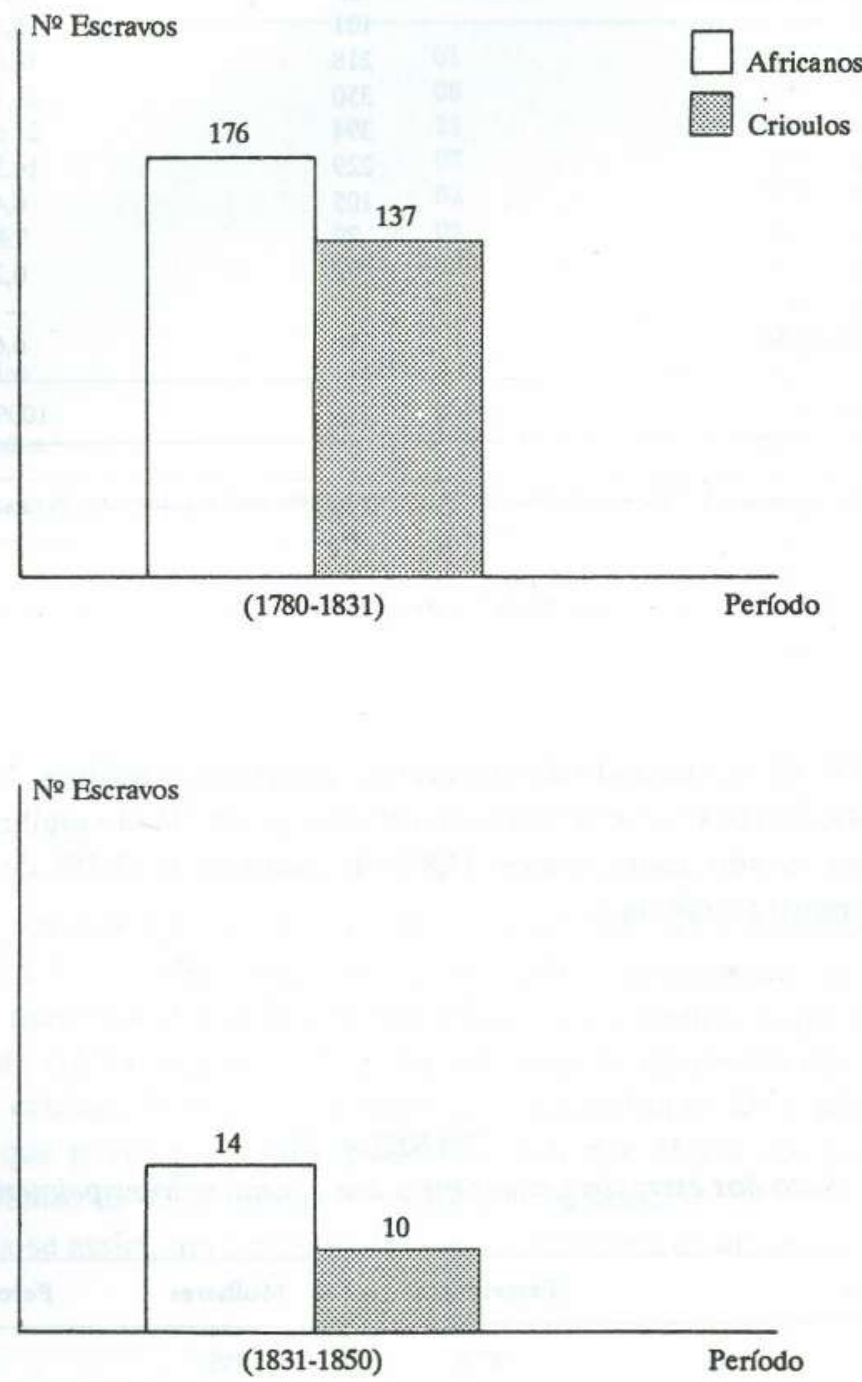


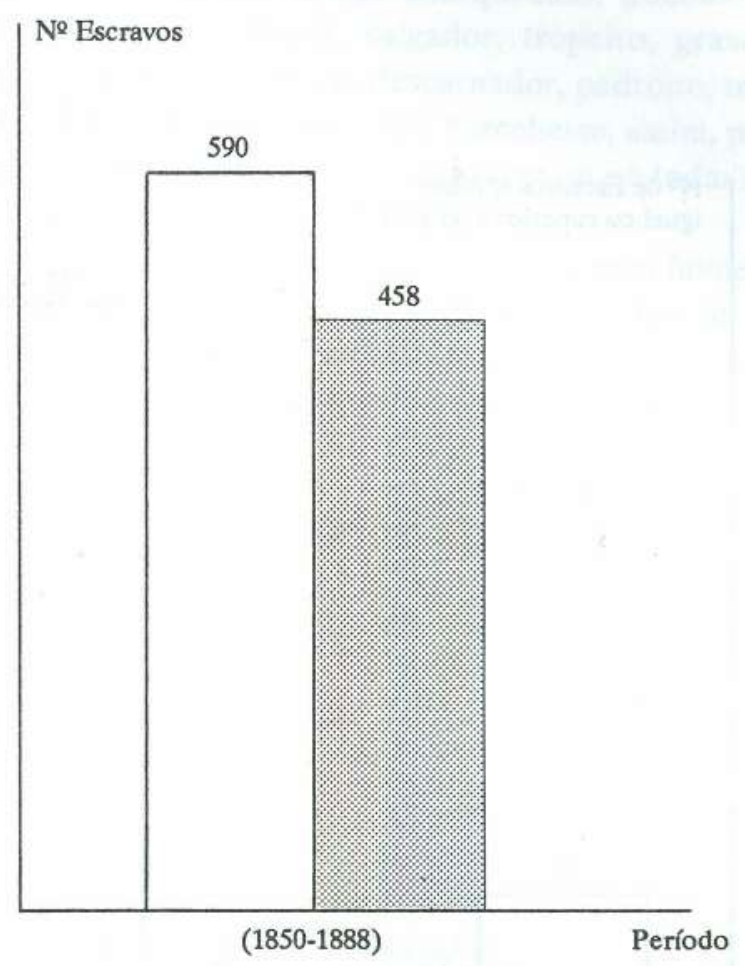

Entre as várias nações africanas destacamos: moçambique, cabidas, monjolo, minas, benguela, rebolo, congo, nagô, angola, sendo a mina a mais numerosa, com numero superior a uma centena de pessoas.

Usando como referencial a idade, a escravaria apresenta, na primeira parte do estudo, $71,1 \%$ com menos de 40 anos; na segunda, $57 \%$ e na terceira, $45,9 \%$.

Podemos concluir que houve um envelhecimento progressivo do escravo. Tal fato se deu provavelmente graças as leis citadas, anteriormente, principalmente a Eusébio de Queiróz, que forçou um aproveitamento do homem servil até suas últimas forças. Basta observarmos o gráfico, a seguir, para percebermos o crescimento do numero de homens idosos. Com idade igual ou superior a 60 anos. 
Idade, sexo, ocupação e...

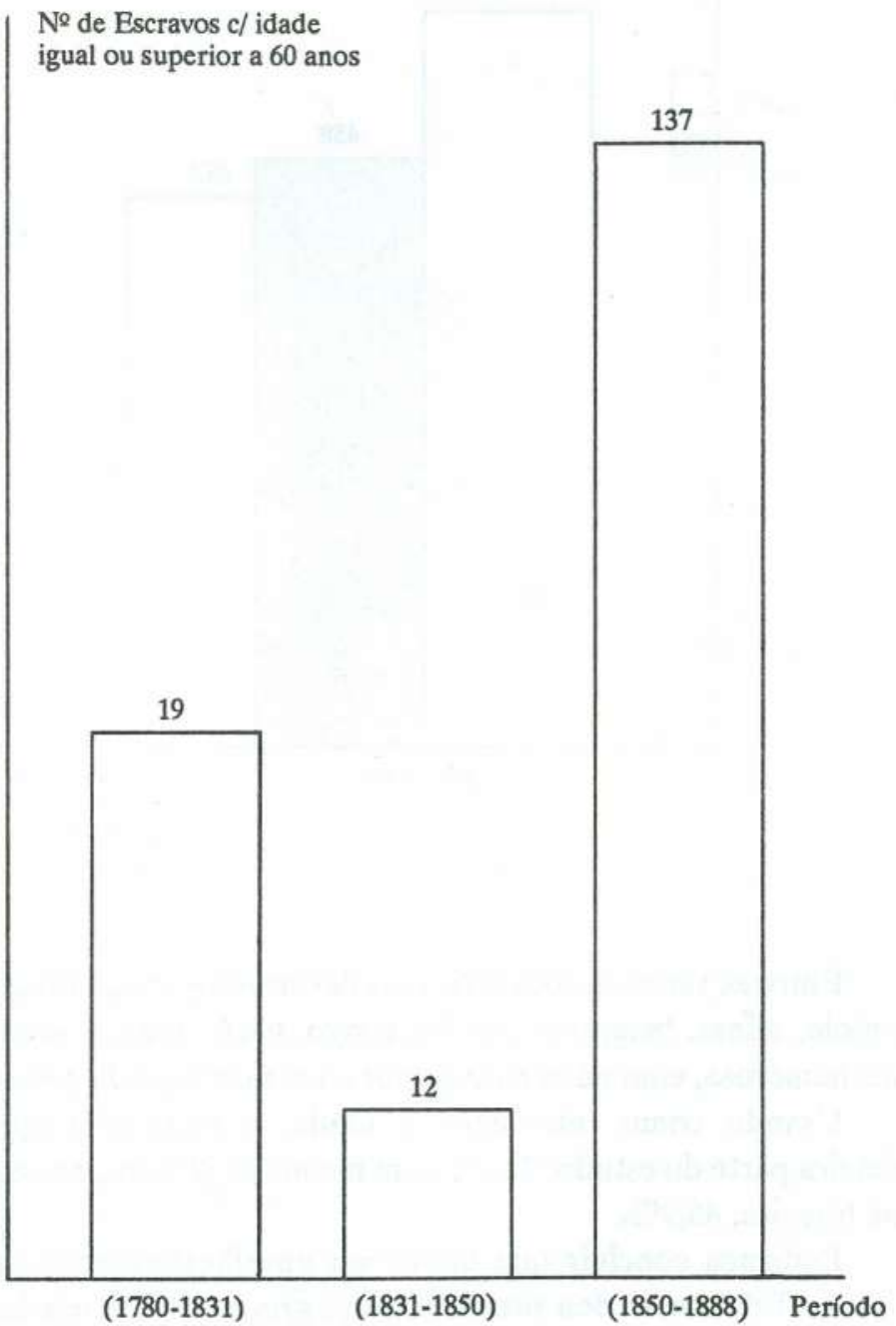


Tratando-se das profissões, nas charqueadas, podemos citar algumas como: carneador, servente, salgador, tropeiro, graxeiro, cozinheiro, alfaiate, carpinteiro, taipeiro, descarnador, pedreiro, marinheiro, campeiro, lavadeiro, bolieiro, roceiro, etc. Percebe-se, assim, pelo estudo dos inventários, que os negros eram utilizados em quase todas as funçôes das charqueadas.

Os charqueadores pelotenses preferiam o escravo homem. Talvez devido à rusticidade das operações realizadas, o uso do elemento feminino se deu em pequena escala. O que também mostra o descaso dos estabelecimentos saladeris em manter uma família escrava.

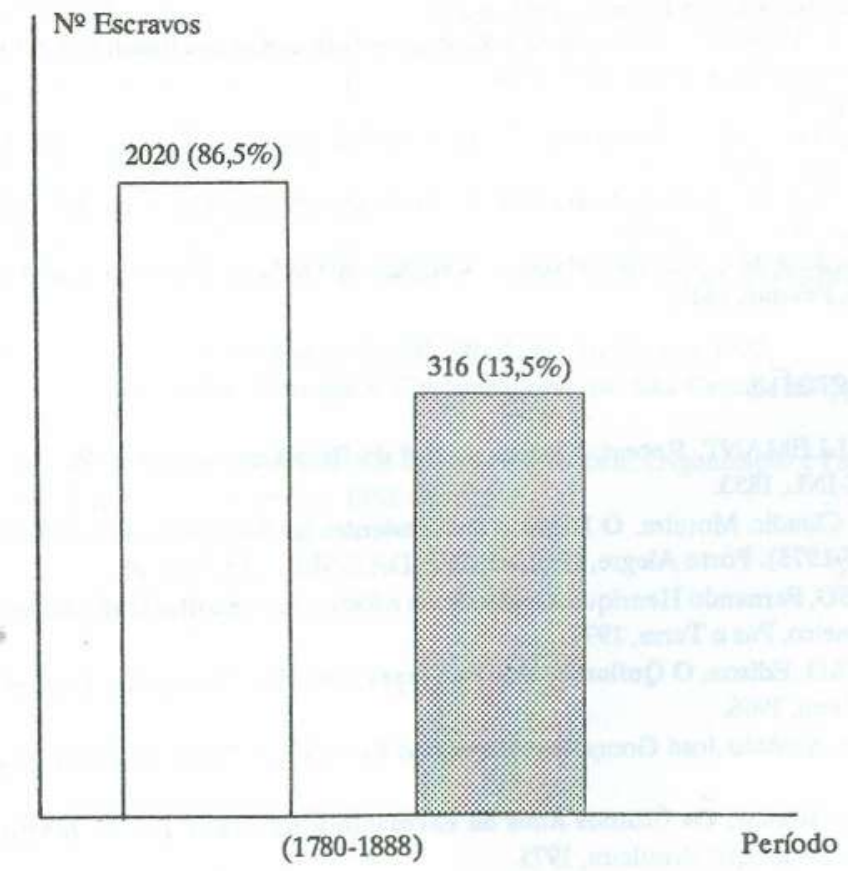

Homens

Mulheres 
Somando-se as três etapas do trabalho, teremos um elevado percentual de homens que chega a $86,5 \%$. Enquanto as mulheres ficam somente nos $13,5 \%$. Ao analisarmos os dados citado, evidencia-se o pouco uso da mão-de-obra feminina nos estabelecimentos saladeiris. Partindo desta idéia, pode-se concluir que os charqueadores pouco se preocupavam com a reprodução natural dos escravos. Assunto que poderá ser desenvolvido, futuramente, com o auxílio de outras fontes.

\section{Notas}

1. Bento, Claudio Moreira. O Negro e Descendentes na Sociedade do Rio Grande do Sul. Porto Alegre, GRAFOSUL-DAC-SEC, 1976.

2. Maestri Fe, Mário José. O Escravo no Rio Grande do Sul. Porto Alegre, EDUCS-EST, 1984. p.56.

3. Marques, Alvarino da Fonseca. Evolução das Charqueadas Rio-Grandenses. Porto Alegre, Martins Livreiro, 1990. p.111.

4. Cardoso, Fernando Henrique. Capitalismo e Escravidáo no Brasil Meridional. Rio de Janeiro, Paz e Terra, 1977. p.66.

5. Idem, p.68.

6. Butuhy, Barăo de. Inventário. $1^{2}$ Cartório de Órfãos e Provedoria, n² 6421, Mç 41, E. 25. Pelotas, 1867.

7. Dreys, Nicolau. Notícia Descritiva da Província de São Pedro do Sul. Porto Alegre, SEC-IEL, 1961. p.168.

8. Santos, José da Costa. Inventário. $1^{\circ}$ Cartório de Órfãos e Provedoria, n²113, Mç 09, E. 25, Pelotas, 1827.

\section{Bibliografia}

AVÉ-LALLEMANT, Robert. Viagem ao Sul do Brasil no Ano de 1858. Rio de Janeiro, MEC-INL, 1853.

BENTO, Claudio Moreira. O Negro e Descendentes na Sociedade do Rio Grande do Sul (1635-1975). Porto Alegre, Grafosul-IEL-DAC-SEC, 1976. Vol. 05.

CARDOSO, Fernando Henrique. Capitalismo e Escravidão no Brasil Meridional. 2.ed., Rio de Janeiro, Paz e Terra, 1977.

CARNEIRO, Edison. O Quilombo dos Palmares. 3.ed., Rio de Janeiro, Livraria Civilizaçăo Brasileira, 1966.

CHAVES, Antônio José Gonçalves. Memórias Econômico-Políticas. Porto Alegre, ERUS, 1978.

CONRAD, Robert. Os Últimos Anos da Escravatura no Brasil. Rio de Janeiro, MEC-Livraria Civilização Brasileira, 1975.

COUTY, Louis. Le Maté et Les Conserves de Viende. Rio de Janeiro, s.ed., 1880.

DACANAL, José Hildebrando [Org.]. RS: Economia \& política. Porto Alegre, Mercado Aberto, 1979.

D'EU, Conde. Vlagem Militar ao Rio Grande do Sul. São Paulo, USP, 1981.

DREYS, Nicolau. Notícia Descritiva da Província de São Pedro do Sul. Porto Alegre, SEC-IEL, 1961. 
FREITAS, Décio. Escravos e Senhores de Escravos. Porto Alegre, UCS-EST, 1977.

-. Palmares. A Guerra dos Escravos. Porto Alegre, Movimento, 1977.

-. Insurreiçôes Escravos. Porto Alegre, Movimento, 1973.

GORENDER, Jacob. O Escravismo Colonial. 2.ed., São Paulo, Ática, 1978.

ISABELLE, Arsène. Viagem ao Rio Grande do Sul (1833-1834). Trad. e notas de Dante de Laytano. Porto Alegre, 1946.

LAYTANO, Dante de. Os Africanos no Dialeto Gaúcho. Porto Alegre, 1936.

LUCCOK, John. Notas sobre o Rio de Janeiro e Partes Meridionais do Brasil. 2.ed., São Paulo, Livraria Martins, 1951.

MAESTRI, Mário José. A Servidão Negra. Porto Alegre, Mercado Aberto, 1988.

-. A Origem do Escravo Gaúcho e a Capitania de São Pedro do Sul. In: Revista do Departamento de Biblioteconomia e História da FURG. Rio Grande, 1978.

-. O Escravo Gaúcho. (Resistência e Trabalho). São Paulo, Brasiliense, 1984.

MAGAlHÃES, Mário Osório. História e Tradiçảo da Cidade de Pelotas. Pelotas, Ponto de Vista, 1979.

MARQUES, Alvarino. Episódios do Ciclo do Charque. Porto Alegre, Edigal, 1987.

MATTOSO, Kátia M. de Queirós. Ser Escravo no Brasil. São Paulo, Brasiliense, 1982.

MOREIRA, Angelo Pires. Pelotas na Tarca do Tempo. Pelotas, 1988.

MOURA, Clóvis. Rebeliōes da Senzala. (Quilombo, Insurreição, Guerrilhas). Rio de Janeiro, Conquista, 1972.

-. Os Quilombos e a Rebeliâo Negra. São Paulo, Brasiliense, 1981.

-. Sociologia do Negro Brasileiro. São Paulo, Ática, 1988.

-. História do Negro Brasileiro. São Paulo, Ática, 1989.

OLIVEIRA, Lúcia Helena Garcia de. O Lugar do Negro na Força de Trabalho. Rio de Janeiro, IBGE, 1986.

RODRIGUES, R. Nina. Os Africanos no Brasil. São Paulo, Brasiliana, 1977.

SPALDING, Valter. Pecuária, Charque e Charqueadores no Rio Grande do Sul. Porto Alegre, 1943.

VIANNA, Oliveira. Populaçôes Meridionais do Brasil. (História, Organização e Psicologia). 5.ed., Rio de Janeiro, José Olympio, $1952.2^{\circ}$ vol. 
ANEXO 1

Inventários

1780-1831

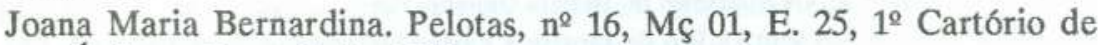
Órfãos e Provedoria, 1810.

Domingos Rodrigues. Pelotas, $\mathrm{n}^{2} 32$, Mç 02, E. 25, $1^{\circledR}$ Cartório de Órfãos e Provedoria, 1818.

José Gonçalves da Silveira Calheca. Pelotas, $\mathrm{n}^{2}$ 56, Mç 05, E. 25, $1^{2}$ Cartório de Órfãos e Provedoria, 1820.

João Nunes Batista. Pelotas, $\mathrm{n}^{2} 75$, Mç 06, E. $25,1^{\circ}$ Cartório de Órfãos e Provedoria, 1823.

Cecília Rodrigues das Silva. Pelotas, $\mathrm{n}^{2}$ 83, Mç 07, E. 25, $1^{2}$ Cartório de Órfãos e Provedoria, 1824.

José Pinto Martins. Pelotas, $n^{\circ} 144$, Mç 10, E. 25, $1^{\circ}$ Cartório de Órfãos e Provedoria, 1827.

1831-1850

Francisca Alexandrina da Costa. Pelotas, nã 2193, Mç 21, E. 25, $1^{2}$ Cartório de Órfãos e Provedoria, 1848.

Joaquina Maria da Silva. Pelotas, nã 304, Mç 21, E. 25, $1^{2}$ Cartório de Órfãos e Provedoria, 1849.

Manoel Soares da Silva. Pelotas, $\mathrm{n}^{\circ} 318$, Mç 22, E. 25, $1^{\circ}$ Cartório de Órfãos e Provedoria, 1850.

1859-1888

Virgínia Souzada de Campos. Pelotas, n² 335, Mç 23, E. 25, $1^{2}$ Cartório de Órfãos e Provedoria, 1851.

Visconde de Jaguari. Pelotas, n 348, Mç 26, E. 25, $1^{2}$ Cartório de Órfãos e Provedoria, 1852.

João Simōes Lopes Neto. Pelotas, n 336, Mç 26, E. 25, $1^{\circ}$ Cartório de Órfãos e Provedoria, 1853.

João Guerino Vinhas. Pelotas, $n^{2} 383$, Mç 26, E. 25, $1^{2}$ Cartório de Órfãos e Provedoria, 1854.

José Vieira Vianna. Pelotas, n² 383, Mç 26, E. 25, $1^{\circledR}$ Cartório de Órfãos e Provedoria, 1854.

Albana dos Santos Barcellos. Pelotas, n 406, Mç 28, E. 25, $1^{\circ}$ Cartório de Órãos e Provedoria, 1856.

Boa Ventura Rodrigues Barcellos. Pelotas, $\mathrm{n}^{2} 409$, Mç 28, E. 25, $1^{\circ}$ Cartório de Órfãos e Provedoria, 1856. 
Euphrasia Gonçalves Lopes. Pelotas, $n^{2} 432$, Mç 29, E. 25, $1^{2}$ Cartório de Órfãos e Provedoria, 1857.

Matilde da Silva Vinhas. Pelotas, $\mathrm{n}^{2} 567$, Mç 36, E. 25, $1^{2}$ Cartório de Órfãos e Provedoria, 1862.

Ignácio Rodrigues Barcellos. Pelotas, n² 55, Mç 36, E. 25, $1^{2}$ Cartório de Órfãos e Provedoria, 1863.

Manoel Batista Teixeira. Pelotas, $\mathrm{n}^{0} 579$, Mç 37, E. 25, $1^{\circ}$ Cartório de Órfãos e Provedoria, 1864.

Maria Antonia Coelho Cunha. Pelotas, $\mathrm{n}^{2}$ 603, Mç 39, E. 25, $1^{\circ}$ Cartório de Órfãos e Provedoria, 1865.

Joaquim Guilherme da Costa. Pelotas, n² 599, Mç 38, E. 25, $1^{2}$ Cartório de Órfãos e Provedoria, 1865.

José Ignácio da Cunha. Pelotas, $n^{2} 60$, Mç 38, E. $25,1^{2}$ Cartório de Órfãos e Provedoria, 1865.

João Vinhas. Pelotas, n 642 , E. $25,1^{2}$ Cartório de Órfãos e Provedoria, 1867.

Barão do Butuhy. Pelotas, $n^{\circ} 647$, Mç 41, E. 25, $1^{\circ}$ Cartório de Órfãos e Provedoria, 1867.

Leonídia Gonçalves Correia. Pelotas, n² 647, Mç 41, E. 25, $1^{2}$ Cartório de Órfãos e Provedoria, 1867.

Silvana Cluidina Belchior. Pelotas, $n^{\circ} 727$, Mç 44, E. $25,1^{\circ}$ Cartório de Órfãos e Provedoria, 1870.

Cypriano Joaquim Rodrigues Barcellos. Pelotas, $\mathrm{n}^{2}$ 02, Mç 01, E. 28, 1870.

Carlota Batista Teixeira. Pelotas, $\mathrm{n}^{2} 733$, Mç 44, E. 25, $1^{2}$ Cartório de Órfãos e Provedoria, 1871.

Luiz Teixeira Barcellos. Pelotas, $n^{2} 777$, Mç 46, E. 25, $1^{2}$ Cartório de Orfãos e Provedoria, 1871.

Maria Luiza Chaves. Pelotas, $n^{2} 770$, Mç 46, E. 25, $1^{\circledR}$ Cartório de Órfãos e Provedoria, 1872.

Antonio José Gonçalves Chaves. Pelotas, $\mathrm{n}^{2} 1791$, Mç 45, E. 25, $1^{2}$ Cartório de Órfãos e Provedoria, 1872.

Annibal Antunes Maciel. Pelotas, no 815 , Mç 48, E. 25, $1^{\circ}$ Cartório de Órfãos e Provedoria, 1875.

Francisco Anibal Antunes Maciel. Pelotas, $n^{2} 3063$, Mç 180, E. 26, $1^{2}$ Cartório de Órfãos e Provedoria, 1877.

Silvana Belchior. Pelotas, $\mathrm{n}^{2} 870$, Mç 50, E. $25,1^{2}$ Cartório de Órfãos e Provedoria, 1877.

Rita Teixeira Barcellos. Pelotas, $\mathrm{n}^{2}$ 937, Mç 54, E. 25, $1^{2}$ Cartório de Órfãos e Provedoria, 1880.

Domingos Soares Barbosa. Pelotas, $n^{2}$ 943, Mç 54, E. 25, $1^{2}$ Cartório de Órfãos e Provedoria, 1881. 
Mathildes Vinhas Lopes. Pelotas, $n^{2} 775$, Mç 46, E. 25, $1^{2}$ Cartório de Órfāos e Provedoria, 1883.

Antonio José da Silva Maia. Pelotas, n² 995, Mç 57, E. 25, $1^{2}$ Cartório de Órfãos e Provedoria, 1884.

Jacinto Antonio Lopes. Pelotas, $\mathrm{n}^{2} 1028$, Mç 58, E. 25, $1^{\circ}$ Cartório de Órfãos e Provedoria, 1885.

Eleutério Rodrigues Barcellos. Pelotas, $\mathrm{n}^{2} 1046$, Mç 59, E. 25, $1^{2}$ Cartório de Órfãos e Provedoria, 1886. 